Original article

\title{
Anthropogenic influences on the morphodynamics of the upper Odra channel
}

\author{
Agnieszka Czajka*1, Ádám Nádudvari ${ }^{2}$ \\ ${ }^{1}$ Department of Reconstructing Environmental Change, Faculty of Earth Sciences, University of Silesia, Będzińska Str. 60, \\ Sosnowiec, Poland \\ ${ }^{2}$ Faculty of Earth Sciences, University of Silesia, Będzińska Str. 60, Sosnowiec, Poland \\ E-mail address (*corresponding author): agnieszka.czajka@us.edu.pl
}

\begin{abstract}
The aim of the studies presented in this article was a multifaceted approach to the problem of the processes of river adjustments to new conditions created by channel regulation. The Upper Odra channel has been significantly shortened by meander cut offs and locally by channelization. The influence of those changes on channel morphodynamics and the pattern of bedload transport were calculated. Pre-regulation channel geometry was reconstructed and the channel stability and bedload transport were characterized and compared with the present state. Also the flow duration curves (FDC) for the characteristic water stages and for the average discharges were plotted and analyzed to assess vertical channel bed movement. By comparing the behavior of natural channel sectors (both, present and fossil) to channelized and sectors shortened by cut offs it was possible to understand the intensity of changes depending on a way of channel regulation. The range of post regulation changes in bedload transport and channel stability was also calculated for the functioning, unregulated sector of the Odra channel. Flow duration curves reflect steady channel incision while the protected river banks prevent the channel from lateral movement. In order to achieve lateral stability, which is unnatural for meandering rivers, the Odra channel is totally remodelled and the new geometry and flow conditions created. The morphological response to the training works was channel incision and accelerated bedload transport.
\end{abstract}

KEY WORDS: river regulation, channel stability, river morphodynamics

ARTICLE HISTORY: received 15 February 2016; received in revised form 14 May 2016; accepted 7 June 2016

\section{Introduction}

Humans have played a vital role in changing river channels for more than 4000 years (GREGORY, 2006; Williams ET AL., 2015). Many direct and indirect factors are recognized, which affect the channel planform, cross-section and bedload composition. Direct factors such as training works not only change the channel morphometry but also force the river to adjust its morphodynamics according to the newly created conditions (CSERKÉSZNAGY ET AL., 2010; ZAWIEJSKA \& WYZGA, 2010; DADE ET AL., 2011) because river channel geometry depends on its gradient, water discharge, type of bedload material, sediment load and size, flow kinematics as well as local environmental conditions (Chalov, 1999; Verstraeten ET AL., 2003; Bogen, 2009; MACKLIN ET AL., 2010; DADE ET AL., 2011; DRAUT ET AL., 2011; GORCZYCA ET AL., 2011; NÁDUDVARI
\& CZAJKA, 2014). The significant impact of dam constructions, groin construction, meander cutoffs and sand and gravel extraction is widely known (HOOKE, 2006; KLIMEK \& LATOCHA, 2007; KORPAK, 2007; KISS ET AL., 2008; WISHART ET AL., 2008; CSERKÉSZ-NAGY ET AL., 2010; GORNEY ET AL., 2011; HOFFMANN ET AL., 2010; GENDASZEK ET AL., 2012). Researchers not only try to understand the scale of post regulation changes but also to utilize the results in planning river restoration works (BROOKS \& BRIERLEY, 2004; RINALDI ET AL., 2013). The diversity of parameters influencing river morphodynamics enforces the river investigation to be led within homogenous reaches (HOOKE, 2003; CZAJKA, 2015) but it is widely known that permanent interactions between adjacent reaches determine the entire behavior of the river.

An understanding of processes leading to significant changes in a river's morphodynamics 
is crucial to being able to predict the future possible channel responses to constant human influence (SCHOOR ET AL., 1999; GREGORY ET AL., 2008; ARNAUD ET AL., 2015).

The most notable consequences of channel regulation are incision and bed material coarsening due to an increase in water energy (GLOBEVNIK \& Mikoš, 2009; PARKER ET AL., 2011; TOONEN, 2015). However, in many rivers, channel alteration proceeds as a consequence of in-channel sand and gravel mining (KONDOLF, 1997; ARNAUD ET AL., 2015; YUILL ET AL., 2015; ZAWIEJSKA ET AL., 2015).

Flow duration curves (FDC) are a useful tool to evaluate hydrological characteristics of regimes and flow variability (BOOKER \& SNELDER, 2012). They show the link between stream flow and the respective frequencies, but their use and reliability depends on the availability of observed data (MEndicino \& SEnATORE, 2013). A flow duration curve can provide information about the integral catchment response to rainfall events, that span from low volume events to events of flood magnitude and it is particularly useful for low flow regime characterization (HOPE \& BART, 2012; LONGOBARDI \& VILLANI, 2013). A FDC represents the relationship between the magnitude and frequency of daily, weekly, monthly (or other time interval) stream flow for a particular river basin, providing an estimate of the percentage of time a given water stage was equaled or exceeded over a historical period (SEARCY, 1959, CASTELLARIN ET AL., 2004).

The present study focused on the humaninduced changes in functioning of the Odra channel attributable to meander cut-offs. Natural, or artificial, chute and neck cutoffs are the most suitable for reconstructing channel changes (ERSKINE ET AL., 1992).

Nearly 200 years after meander cut offs and construction of arrays of groins the river seems to find a new equilibrium. Shortly after regulation, which significantly shortened the river course and narrowed the channel, the increased energy of water concentrated in the channel axis, initiated channel bed incision. The over-bank deposition rate differs over time (CISZEWSKI \& CZAJKA, 2015) and the average rate of that process is lower at present. This is an effect of the increase of channel bank height caused both, by channel incision and long time overbank deposition (CZAJKA \& CISZEWSKI, 2010).

The aim of this study was to use a multifaceted approach to investigate the process of river adjustment to the new, differentiated conditions created by channel regulation.

\section{Study area}

The River Odra drains almost $90 \%$ of Poland's land area (Fig. 1 - I). With a total length of 854,3 $\mathrm{km}$ (742 km of which lie within Poland) and a drainage basin of $118861 \mathrm{~km}^{2}$ The River Odra is the second largest river in Poland. The upper Odra, part of which is discussed in this paper, drains northern slopes of the Sudety Mountains and north-western slopes of the Carpathians. The River Odra flows from the Czech Republic towards the north entering Poland through the Moravian Gate, which is the depression between the Carpathian Mountains in the east and the Sudetes in the west. The Odra valley within the studied sector is in filled with Pleistocene glaciofluvial material underlain by Miocene deposits. The average valley floor elevation is $195 \mathrm{~m}$ asl. and the average channel gradient is about $0.4 \%$ which is not a natural state but has the effect of shortening the Odra channel by about 36\% for navigational purposes. The climate here is temperate continental and the hydrological regime of River Odra is nival-pluvial. The mean discharge in this sector equals $58 \mathrm{~m}^{3} \mathrm{~s}^{-1}$ but the highest discharge recorded in the discussed sector was $2160 \mathrm{~m}^{3} \mathrm{~s}^{-1}$ in Chałupki and $2880 \mathrm{~m}^{3} \mathrm{~s}^{-1}$ in Krzyżanowice during the flood in July 1997, which is the extreme value recorded in the studied reach of River Odra.

The upper Odra training works had already started in the mid-18 ${ }^{\text {th }}$ century, in the beginning by cutting off the largest meanders in the years $1786,1850-1860,1870-1882$ and 1903 . The newly shaped channel and subsequent construction of groin arrays has reduced the natural width of the River Odra nearly twice to an average width of $61 \mathrm{~m}$. Construction of dikes has locally narrowed the floodplain to a mere $200 \mathrm{~m}$, while the natural floodplain is up to $6 \mathrm{~km}$ wide. These artificially created changes in channel geometry have induced its incision by about $3 \mathrm{~m}$ to date and this process was most intensive in $18^{\text {th }}$ century (CZAJKA \& CISZEWSKI, 2010).

Nowadays the entire river course is modified by meanders cut offs and this means that the present Odra channel varies considerably in channel sinuosity and gradient within particular sectors. The upper Odra channel has also been regulated, except for the $7 \mathrm{~km}$ long state border section, which remains naturally meandering.

The study reach is $7 \mathrm{~km}$ long and not uniform in terms of channel geometry. Three sectors of the present Odra channel, and one former section, were chosen for further research, each one morphologically distinct from the others (Fig. 1 - II). 
Sector A - meandering, sector B - straight, channelized, sector C - shortened, sinuous and Sector D - former, meandering Odra channel, non functioning at present, filled with deposits, visible in aerial photos (Fig. 1 - IV). The presented studies are focused on the reconstruction of natural channel morphodynamics and an assessment of the differences in channel adjustment to human induced conditions in geometrically varied channel sectors.

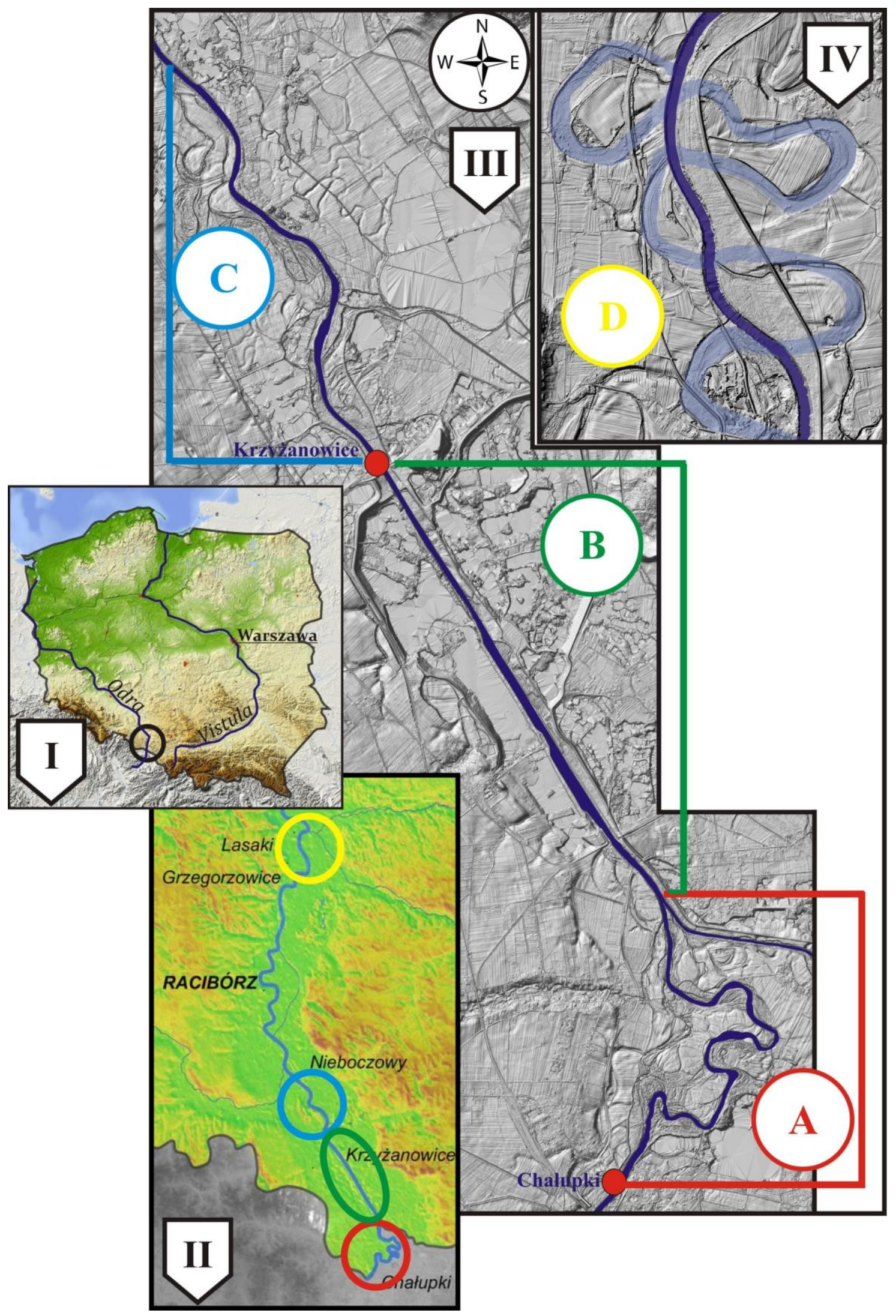

Fig. 1. Study site (I) and location of discussed channel sections (II) with morphologically different sectors of Odra channel (III) and course of preregulation channel (IV), which geometry was reconstructed for the purpose of presented studies 


\section{Material and methods}

Three sectors of the current Odra channel and one former section were selected for further research, each one morphologically distinct from the other. One of them is shortened, one channelized and one remains meandering. The shape of the pre-regulated channel is still clearly visible in the floodplain morphology and in the aerial photos except of the places where the sand and gravel are excavated from the floodplain e.g. along the channelized reach.

Changes in the Odra channel geometry were established both, in planform and in vertical dimensions by compiling present and archival cartographic materials and by field measurements of the width of cut off meanders. To assess the depth of cut off meanders a series of drillings were made by means of a hand auger. Cut off meanders are in filled with flood deposits, mainly sand, silty sand and silt and the depth of the former channel was established at the level of gravel representing the bedload of the pre-regulated Odra channel. Samples of bedload material were taken both, from the former channel and from the current channel bed in each discussed sector. Also samples of deposits from the current channel bars were analyzed as river bed material.

Samples from the current channel were analyzed from existing gravel bars formed during high water stages. The gravel bars surfaces are imbricated. Samples were taken from surface and subsurface layers. The surface layers were measured using a $1 \mathrm{~m}^{2}$ sampling grid frame. The pebbles were counted and the longer axis of each was measured. After removing the surface layer about $0.15 \mathrm{~m}^{3}$ of subsurface material was sieved through 64.32 and $16 \mathrm{~mm}$ gravel sieves. Particles finer than 16 mm were manually mixed and $30 \mathrm{~kg}$ of material were taken to the laboratory where the standard dry-sieve analysis was performed. In total 10 samples were measured: 4 in meandering sections, 3 in straight sections and 3 in sinuous sections. For further calculations $\mathrm{D}_{10}, \mathrm{D}_{50}$ and $\mathrm{D}_{90}$ were calculated.

The former channel was sampled using a hand corer. Since the diameter of the auger is only $5 \mathrm{~cm}$ the size of the pebbles it was possible to collect was very limited. For this reason samples from the bottom cut off meanders were analyzed as the subsurface layer. The remnants of surface layer cut off meanders were found in excavations made in the Odra river bank where the present channel crosses the former channel.

The water stages and discharges were analyzed at 2 gauging stations: Chałupki (meandering section), Krzyżanowice (border of straight and sinuous sections) and Racibórz Miedonia (values of discharge for the pre-regulated channel). Average water level and discharge, bankfull water level and discharge and big flood water level and discharge were calculated for each station. The water level and discharge measured during the flood in 1997 were considered as values for the big flood. The obtained data were used for further calculations of channel morphodynamics.

Using daily hydrological data the flow and discharge duration curves were plotted for the Chałupki and Krzyżanowice gauging stations. The flow duration curve (FDC) is a cumulative frequency curve that shows the percentage of time specified discharges, or water levels, were equaled or exceeded during a given period. Data for FDCs for Chałupki and Krzyżanowice were grouped in decades for a clear picture of the variation in the curves (Fig. 2). It is assumed that the trend in the behavior of the curves for the duration of the minimum stages illustrates the vertical movements of the river channel bottom (BOOKER \& SNELDER, 2012).

To establish the channel stability and dynamics of the channel bedload changes such parameters as Bonnefille particle number $\left(D^{*}\right)$ and Shield's mobility number $(\theta)$ were derived for each of chosen channel sectors.

(1) Non-dimentional grain size - Bonnefille parameter $\mathrm{D}^{*}$ was calculated as:

$D^{*}=\sqrt[s]{\frac{\mathrm{Rg}}{\mathrm{v}^{2}}}$

where: $D_{50}=50^{\text {th }}$ percentile of the grain size distribution, $R=\left(\rho_{s}-\rho\right) / \rho$ resultant of water and sediment density, $g=$ acceleration due to gravity in $\mathrm{m} \mathrm{s}^{-2}, v$ - water viscosity

(2) Shield's number $\theta$ (dimensionless shear stress) is defined as:

$\theta=\frac{\tau}{\left(\rho_{s}-\rho\right) g D_{50}}$

where $\rho$ and $\rho s$ are the density $\left(\mathrm{kg} \mathrm{m}^{-3}\right)$ of fresh water and sediment, respectively.

(3) Shear stress $\tau\left[N \cdot m^{2}\right]$ is defined as $\tau=\rho g h s$

where: $\rho$ - fresh water density $\left(\mathrm{kg} \mathrm{m}^{-3}\right), \mathrm{g}=$ acceleration due to gravity in $\mathrm{m} \mathrm{s}^{-2}, \mathrm{~h}$ - channel depth, s - channel bed slope.

Additionally Lokhtin index and Makkavejev number were calculated for each of studied sectors and for 3 characteristic discharges respectively. These two parameters are not widely known although they seem to be useful for channel stability prediction. The stability coefficients allow for simple estimation of channel vulnerability to 
erosion and accumulation processes due to specific hydrological conditions.

(4) Lokhtin index is calculated as:

$\eta_{\mathrm{L}}=\frac{\mathrm{D}_{50}}{\mathrm{~S}}$

and (5) Makkaveev number is derived from:
$\eta_{\mathrm{M}}=\frac{\mathrm{D}_{50}}{\mathrm{~W} * \mathrm{~S} * 1000}$

where $D_{50}-50^{\text {th }}$ percentile of the grain size distribution (mm), $S$ - channel slope (\%), $W$ channel width (m) inform about channel stability by given ranges (Table 1 ).

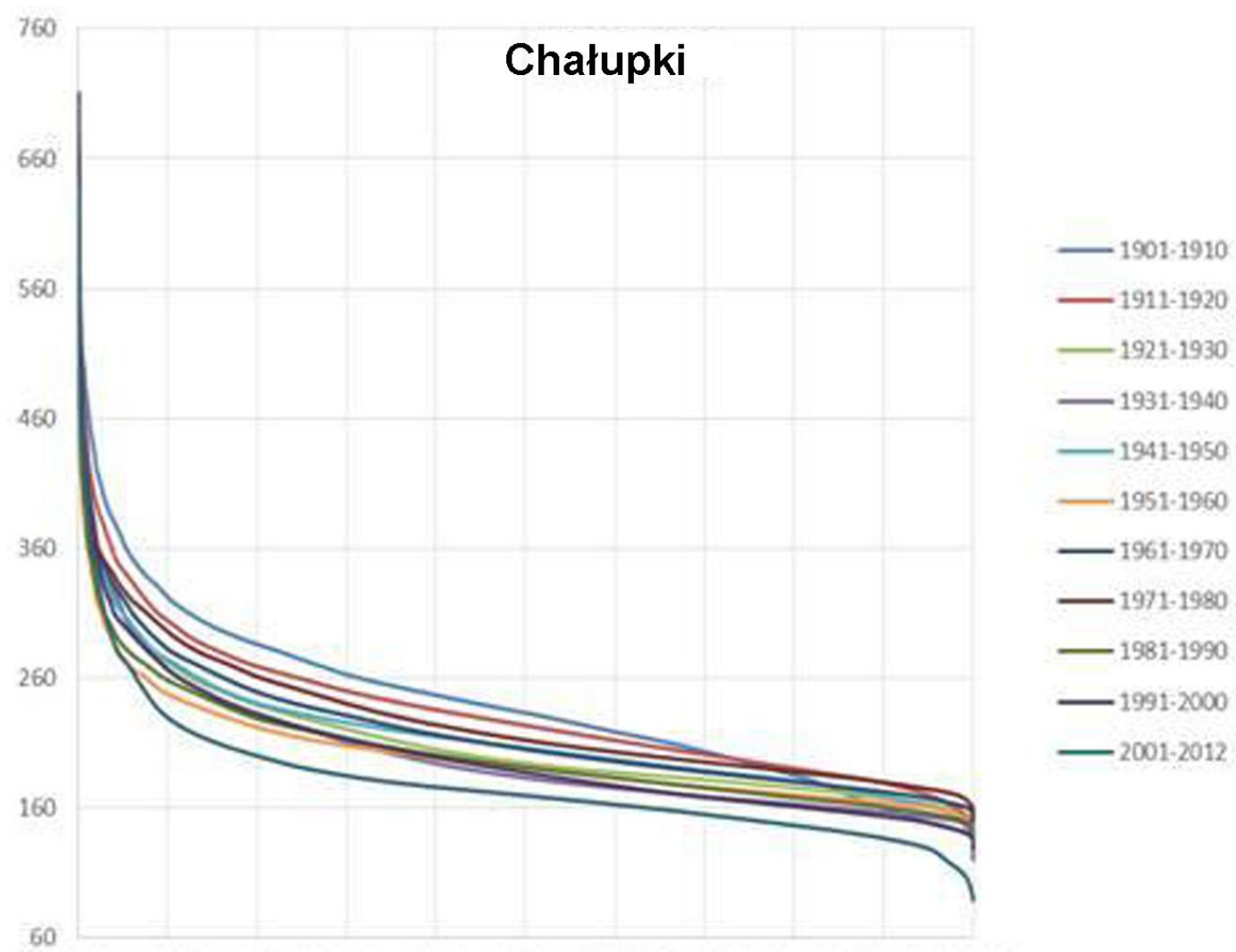

A

$0,00 \% \quad 10,00 \% \quad 20,00 \% \quad 30,00 \% \quad 40,00 \% \quad 50,00 \% \quad 60,00 \% \quad 70,00 \% \quad 80,00 \% \quad 90,00 \% 100,00 \%$

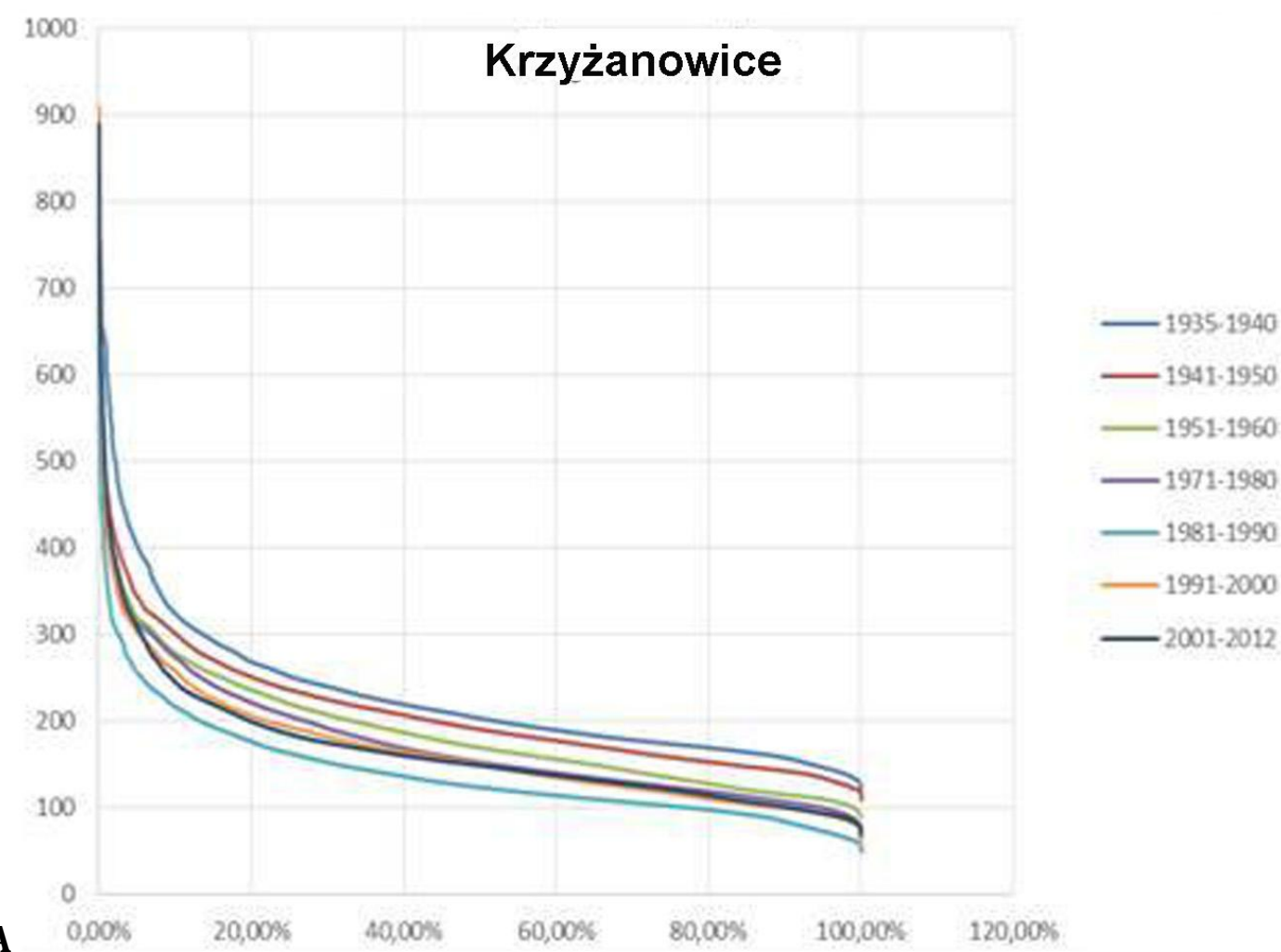



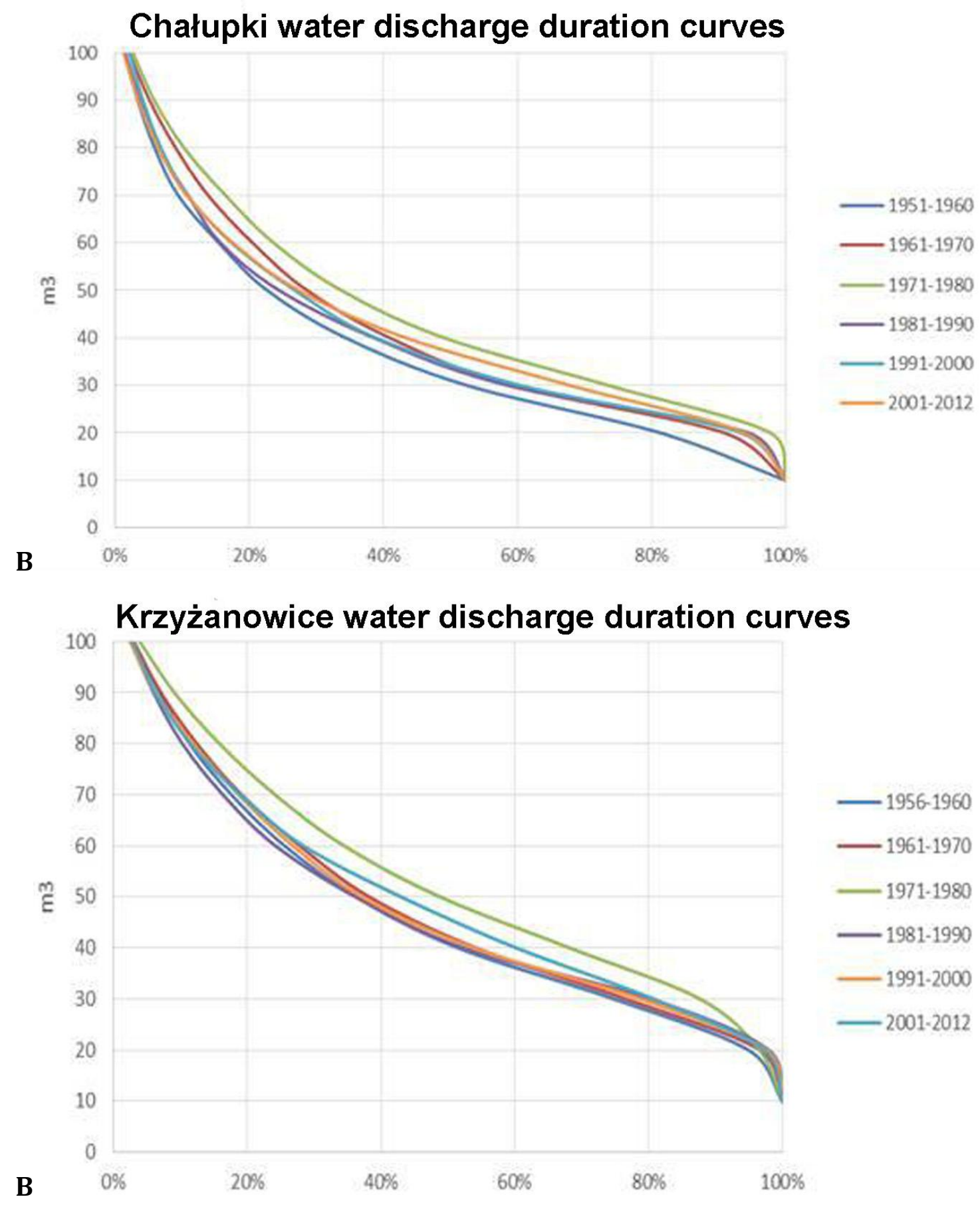

Fig. 2. Flow duration curves for Chałupki and Krzyżanowice gauging stations. (A) daily water level duration, (B) daily discharge duration

Table 1. Ranges of channel stability, by Lokchtin ( $\eta \mathrm{L})$ and by Makkavejev ( $\eta \mathrm{M})$

\begin{tabular}{|l|c|c|}
\hline \multicolumn{1}{|c|}{ Channel stability } & $\eta \mathrm{L}$ & $\eta \mathrm{M}$ \\
\hline Unstable channel & $<2$ & $<6$ \\
\hline Channel of low stability & $2-5$ & $6-15$ \\
\hline Semi stable channel & $5-10$ & $15-20$ \\
\hline Stable channel & $10-50$ & $20-100$ \\
\hline Channel of high stability & $>50$ & $>100$ \\
\hline
\end{tabular}


Parameters were calculated for average and bankfull discharge as well as for the big flood for the present channel in each studied section and separately for the pre-regulated channel. The flow duration curve (FDC) is a cumulative frequency curve that reflects the percent of days in which specified discharges, or water levels, were equaled, or exceeded, during a given period. Thus, duration curves are useful in appraising the geological characteristics of drainage basins and the channel bottom vertical movement may be recognized by means of FDC comparisons (SEARCY, 1959).
Odra daily water stages and discharges measured at gauging stations in Chałupki (1901-2012) and Krzyżanowice (1935-2012) were analyzed. On the basis of the data set the diagrams of duration water stages and discharges were plotted in both profiles (Fig. 3). Data for FDCs were grouped in decades for a clear picture of the variation in the curves especially for the duration of low water stages. The declining trend of the curves plotted for the duration of the minimum stages illustrates the vertical movements of the river channel bottom.

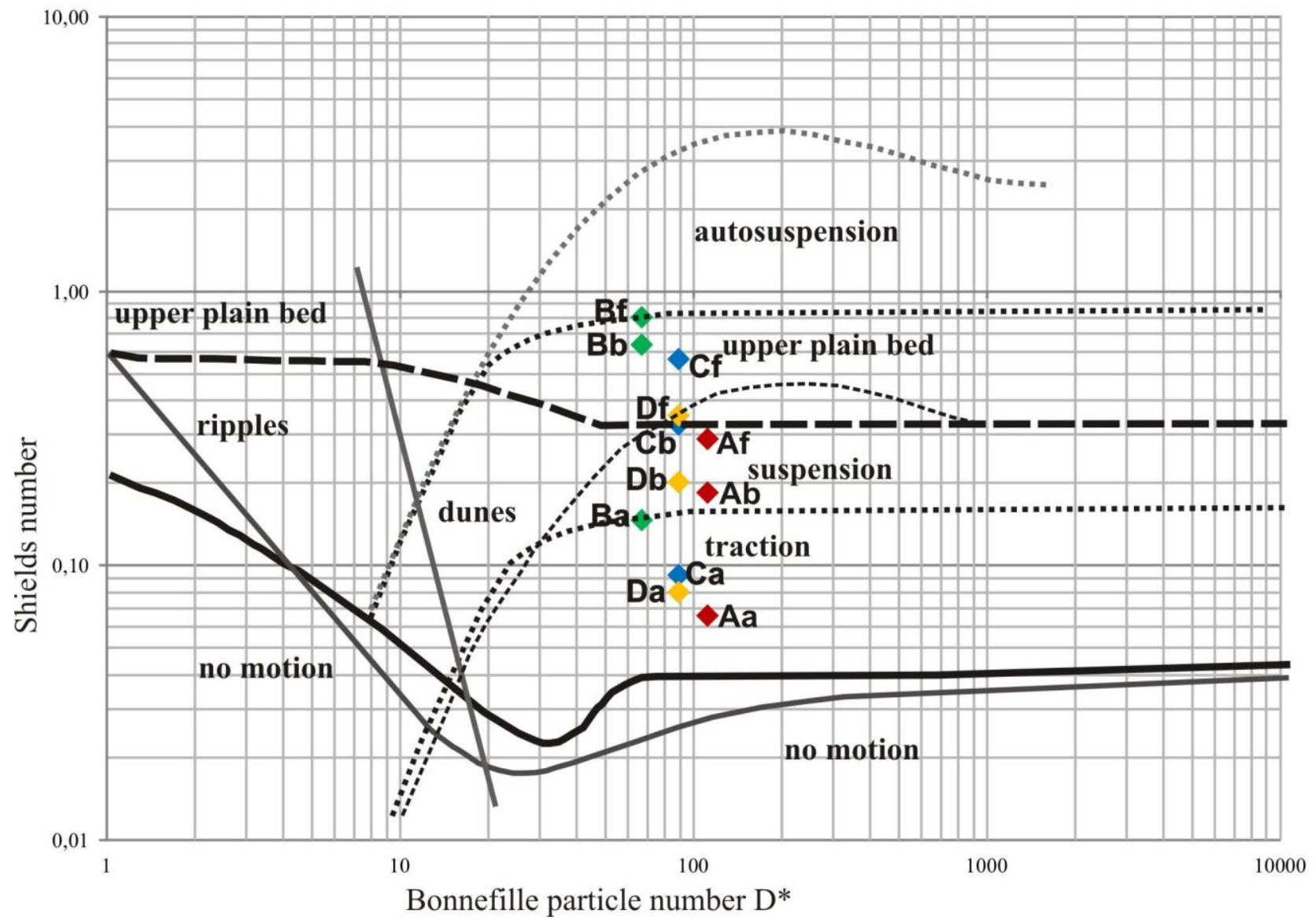

Fig. 3. Sediment movement in studied sectors of Odra river during average water stage, bankfull water stage and during the flood. A - meandering sector, B - channelized sector, C - sinuous sector, D - reference sector; a - average discharge, b - bankfull discharge, $\mathrm{f}$ - flood (compilation of curves after Kleinhans, 2005)

\section{Results}

The new channel equilibrium can be considered over 200 years since the channel regulation took place. The meander cut offs and channel straightening started here in 1786 and were finished in 1821. Since that time regular works such as groin constructions and renovation work have been carried out.

The channel banks are stabilized by rip raps and groins so the river stream stays concentrated far from the banks. Lateral migration of the river channel is impossible in these conditions so one of the main goals of regulation has been achieved:
Odra channel is horizontally stable. At the same time the concentrated water energy implicates bed erosion and as a consequence its incision.

For analysis of the post regulation situation, the vertical channel movement the water stage and water discharge duration curves for the years 1901-2012 were compared. The plotted duration curves reflect the percentage of time when the water stages, or discharges, are equal, or exceed, water stage characteristics for the given gauging station. Diagrams of water stages and discharges reflect not only the hydrological behavior of the river but also the vertical movement of the channel 
bottom in time. In Chałupki the low water level duration curves decrease in the last 30 years compared to the years $1901-1910$ or $1911-1920$, whereas in the last 20-30 years large flood events occurred and increased the average high water stages while the discharges remain at similar level in this period. In Krzyżanowice the low water level duration curves also decrease while the discharges slightly increased. This allows us to conclude, that the decreasing water level duration curves reflect the channel incision rather than changes in climate or land use. Water stages and discharge decrease simultaneously in the case of changes in climate or dam construction.

In the 10 year period 1901-1910 in Chałupki the water level reached a level of $260 \mathrm{~cm}$ for about $40 \%$ of the year. In each of the next decades that value was reached for a shorter time and in the last 10 years only in $5 \%$ of the year. At the same time the water discharges did not decrease and are even higher in the last decade than in years 1990-2000 or 1961-1970. Also in Krzyżanowice the water stages are in general lower than in previous decades except for the years 1981-1990. Water discharge remained stable for the studied period. Comparison of water stages versus discharges for the same period shows that the minimal water stages decrease while the discharge remains stable which suggests channel incision and lowering of the river bed.

Comparison of present and pre-regulated channel bed level also shows significant incision, up to $3.3 \mathrm{~m}$, after the river regulation works which together with major channel narrowing give a completely new geometry to the Odra channel.

Lochtin index and Makkavejev number, calculated for each sector for average, bankfull and flood water stages, gave information about channel stability (Table 2). According to Lochtin index the present meandering sector $(A)$ remains stable in any flow conditions similar to the pre-regulated sector D. The channelized sector B and sinuous sector C may be considered as semi-stable channels. The Makkavejev number gives a more detailed rating of stability in different flow conditions so the results vary from those for the Lochtin index. Therefore, sector A remains stable during average and bankfull water stages, but during flood this sector shows low stability. Sector B, which is channelized loses its stability during the bankfull stage and is unstable during flood. The sinuous sector $\mathrm{C}$ remains stable during average and bankfull stages and floods cause low channel stability. The reconstructed sector $\mathrm{D}$ used to be of low stability during average and bankfull stages and unstable during floods.

Variable water stages create unstable conditions for bedload transport (Fig. 3). Traction is a main way of sediment transport at average flow conditions in sectors $A, C$ and D. Higher water energy in the straight sector $B$ even allows for the suspension which is possible in sectors A, C and D during bankfull stages. Also during flood suspension continues in sector A. In flood conditions the bedload is washed out and upper plain bed is created in sectors $\mathrm{B}, \mathrm{C}$ and $\mathrm{D}$.

Table 2. Lokchtin index and Makkavejev number calculated for studied sectors of Odra channel

\begin{tabular}{|c|c|c|c|c|c|c|c|c|c|c|c|c|}
\hline & \multicolumn{3}{|c|}{ Sector A } & \multicolumn{3}{|c|}{ Sector B } & \multicolumn{3}{|c|}{ Sector C } & \multicolumn{3}{|c|}{ Sector D } \\
\hline & 1 & 2 & 3 & 1 & 2 & 3 & 1 & 2 & 3 & 1 & 2 & 3 \\
\hline$\eta L$ & 15,15 & 15,15 & 15,15 & 7,50 & 7,50 & 7,50 & 10,53 & 10,53 & 10,53 & 12,12 & 12,12 & 12,12 \\
\hline$\eta M$ & 27,50 & 24,19 & 12,89 & 18,99 & 12,24 & 1,59 & 31,67 & 22,89 & 6,51 & 13,20 & 7,14 & 1,65 \\
\hline
\end{tabular}

\section{Conclusions and discussion}

The main idea behind regulation of the River Odra was to make the channel less sinuous and more stable, therefore, more suitable for navigation. However, the first aim has been easily reached but the stability of regulated channel sectors seems not to have been achieved.

The parameters calculated for the chosen sectors of the River Odra channel allow comparisons of conditions of water flow and material transport influencing the channel stability (Table 3). The results reflecting the past river conditions and the significance of human interference may be useful for restoration work planners.

It is widely known that channel stability depends on numerous factors and in the natural state rivers adapt to changing conditions and remain in a state of dynamic equilibrium. Factors influencing river stability are changing constantly and the process of river accommodation is unceasing. The aim of river regulation is, in general, channel stability, which is favourable for navigation purposes and is believed to be a highly effective method in flood control strategy. Navigation requires channels wide and deep enough for barge traffic. Also the 
river bends must be wide enough for this purpose and meandering rivers are regulated by a series of cut offs straightening the river course. In order to stop channel lateral movement the arrays of groins are constructed to keep the current away from banks and prevent them from erosion. By the $18^{\text {th }}$ century, work on the upper Odra regulation had started although engineers were not consented to the proper techniques of works and especially to the potential side effects during future floods. In fact, the regulation works created an entirely new river as the discharge is the only parameter comparable to those in the pre-regulated channel.
The parameters of channel geometry, such as length, sinuosity, slope, depth and width remained approximate to the natural Odra channel only in meandering sector A. As a natural effect of such serious changes the new channel stability and new conditions for sediment transport processes came into being. Lateral stability of the channel implicates its vertical instability of the upper Odra channel. Both of these instabilities are adverse for humans. Lateral instability causes bank erosion and the vertical one lowers the ground water level at the floodplain and is harmful for local ecosystems.

Table 3. Parameters of flow and material transport in studied sectors of Odra river, each for 3 different water stages: average (a), bankfull (b) and for flood (f)

\begin{tabular}{|c|c|c|c|c|c|c|c|c|c|c|c|c|}
\hline \multirow[b]{2}{*}{ Parameters } & \multicolumn{3}{|c|}{ Sector A } & \multicolumn{3}{|c|}{ Sector B } & \multicolumn{3}{|c|}{ Sector C } & \multicolumn{3}{|c|}{ Sector D } \\
\hline & $\begin{array}{c}\mathrm{Q} \\
{[\mathrm{m} 3 / \mathrm{s}]} \\
\text { (a) }\end{array}$ & $\begin{array}{c}\mathrm{Q} \\
{[\mathrm{m} 3 / \mathrm{s}]} \\
\text { (b) }\end{array}$ & $\begin{array}{c}\mathrm{Q} \\
{[\mathrm{m} 3 / \mathrm{s}]} \\
\text { (f) }\end{array}$ & $\begin{array}{c}\mathrm{Q} \\
{[\mathrm{m} 3 / \mathrm{s}]} \\
\text { (a) }\end{array}$ & $\begin{array}{c}\mathrm{Q} \\
{[\mathrm{m} 3 / \mathrm{s}]} \\
\text { (b) }\end{array}$ & $\begin{array}{c}\mathrm{Q} \\
{[\mathrm{m} 3 / \mathrm{s}]} \\
\text { (f) }\end{array}$ & $\begin{array}{c}\mathrm{Q} \\
{[\mathrm{m} 3 / \mathrm{s}]} \\
\text { (a) }\end{array}$ & $\begin{array}{c}\mathrm{Q} \\
{[\mathrm{m} 3 / \mathrm{s}]} \\
\text { (b) }\end{array}$ & $\begin{array}{c}\mathrm{Q} \\
{[\mathrm{m} 3 / \mathrm{s}]} \\
\text { (f) }\end{array}$ & $\begin{array}{c}\mathrm{Q} \\
{[\mathrm{m} 3 / \mathrm{s}]} \\
\text { (a) }\end{array}$ & $\begin{array}{c}\mathrm{Q} \\
{[\mathrm{m} 3 / \mathrm{s}]} \\
\text { (b) }\end{array}$ & $\begin{array}{c}\mathrm{Q} \\
{[\mathrm{m} 3 / \mathrm{s}]} \\
\text { (f) }\end{array}$ \\
\hline $\begin{array}{l}\text { Flow velocity } v \\
{[\mathrm{~m} / \mathrm{s}]}\end{array}$ & 0.42 & 1.26 & 2.34 & 0.49 & 0.61 & 0.37 & 0.73 & 1.26 & 1.27 & 0.35 & 0.64 & 0.51 \\
\hline $\begin{array}{l}\text { Shear stress } \tau \\
{\left[\mathrm{N} / \mathrm{m}^{2}\right]}\end{array}$ & 5.3 & 14.9 & 23.3 & 7.1 & 31.0 & 38.8 & 5.9 & 21.1 & 36.3 & 5.2 & 12.9 & 22.6 \\
\hline $\begin{array}{l}\text { Shields mobility } \\
\text { number } \theta\end{array}$ & 0.065 & 0.184 & 0.228 & 0.145 & 0.638 & 0.800 & 0.092 & 0.326 & 0.561 & 0.080 & 0.200 & 0.350 \\
\hline $\begin{array}{l}\text { Bonnefille particle } \\
\text { number } D^{*}\end{array}$ & 112 & 112 & 112 & 67 & 67 & 67 & 90 & 90 & 90 & 90 & 90 & 90 \\
\hline Lokhtin index & 15.15 & 15.15 & 15.15 & 7.50 & 7.50 & 7.50 & 10.53 & 10.53 & 10.53 & 12.12 & 12.12 & 12.12 \\
\hline $\begin{array}{l}\text { Makkavejev } \\
\text { number }\end{array}$ & 27.5 & 24.19 & 12.89 & 18.99 & 12.24 & 1.59 & 31.67 & 22.89 & 6.51 & 13.20 & 7.14 & 1.65 \\
\hline
\end{tabular}

By comparing the morphodynamics of reconstructed and natural Odra channels in sector $\mathrm{D}$ to those in other sectors a real assessment of human influence was possible. At present the processes of material transport in sector A remain the most similar to natural processes, nevertheless, channel stability in general is much higher in all studied sectors.

The presented studies may be an example of the necessary additional analysis important in planning the restoration works of previously meandering river channels. Profound studies of the morphological processes in pre-regulation channels may be useful to avoid "new regulation" instead of river restoration.

\section{References}

Arnaud F., Piégay H., Schmitt L., Rollet A. J., Ferrier V., Béal D. 2015. Historical geomorphic analysis (1932-2011) of a by-passed river reach in process-based restoration perspectives: The Old Rhine downstream of the Kembs diversion dam (France, Germany). Geomorphology, 236(0): 163-177.

Bogen J., 2009. The impact of environmental changes on the sediment loads of Norwegian rivers. Catena, 79(3): 251-256.

Booker D.J., Snelder T.H. 2012. Comparing methods for estimating flow duration curves at ungauged sites. J. Hydrol., 434435(APRIL 2012): 78-94.

Brooks A.P., Brierley G.J. 2004. Framing realistic river rehabilitation targets in light of altered sediment supply and transport relationships: Lessons from East Gippsland, Australia. Geomorphology, 58(1-4): 107-123.

Castellarin A., Galeati G., Brandimarte L., Montanari A., Brath A. 2004. Regional flow-duration curves: reliability for ungauged basins. Adv. Water Res., 27: 953-965.

Chalov R.S. 1999. Typology of River Channel Processes and the Regional Differentiation of River Channels in Russia. Prace Geogr., 104: 125-139.

Ciszewski D., Czajka A. 2015. Human-induced sedimentation patterns of a channelized lowland river. Earth Surf. Proc. Land., 40(6): 783-795.

Cserkész-Nagy Á., Tóth T., Vajk Ö., \& Sztanó O. 2010. Erosional scours and meander development in response to river engineering: Middle Tisza region, Hungary. Proc. Geol. Associat., 121(2): 238-247.

Czajka A. 2015. The upper Odra as a case study of the impact of channel regulation on its morphodynamics. Ann. Warsaw Univ. Life Sci.-SGGW. 46(46): 91-99.

Czajka A., Ciszewski D. 2010. Deposition of overbank sediments within a regulated reach of the the upper Odra River, Poland. In IAHS-AISH Publ.: 137-142.

Dade W.B., Renshaw C.E., Magilligan F.J. 2011. Sediment transport constraints on river response to regulation. Geomorphology, 126(1-2): 245-251.

Draut A.E., Logan J.B. \& Mastin M.C. 2011. Channel evolution on the dammed Elwha River, Washington, USA. Geomorphology, 
127(1-2): 71-87.

Erskine W., McFadden C., Bishop P. 1992. Alluvial cutoffs as indicators of former channel conditions. Earth Surf. Proc. Land., 17(1): 23-37.

Gendaszek A.S., Magirl C.S., Czuba C.R. 2012. Geomorphic response to flow regulation and channel and floodplain alteration in the gravel-bedded Cedar River, Washington, USA. Geomorphology, 179: 258-268.

Globevnik L., Mikoš M. 2009. Boundary conditions of morphodynamic processes in the Mura River in Slovenia. Catena, 79(2009): 265-276.

Gorczyca E., Krzemień K., Łyp M. 2011. Contemporary trends in the Białka river channel development in the western carpathians. Geogr. Polon., 84(SUPPL. 2): 39-53.

Gorney R.M., Ferris D.R., Ward A.D., Williams L.R. 2011. Assessing channel-forming characteristics of an impacted headwater stream in Ohio, USA. Ecol. Engin., 37(3): 418-430.

Gregory K.J. 2006. The human role in changing river channels. Geomorphology, 79(3-4): 172-191.

Gregory K.J., Benito, G, Downs P.W. 2008. Applying fluvial geomorphology to river channel management: Background for progress towards a palaeohydrology protocol. Geomorphology, 98(1-2): 153-172.

Hoffmann T., Thorndycraft V.R., Brown A.G., Coulthard T.J., Damnati B., Kale V.S., Middelkoop H., Notebaerd B., Walling D.E. 2010. Human impact on fluvial regimes and sediment flux during the Holocene: Review and future research agenda. Global Planet Change, 72(3): 87-98.

Hooke J.M. 2003. River meander behaviour and instability : a framework for analysis. Transact. Inst. British Geogr., 28(2): 238-253.

Hooke J.M. 2006. Human impacts on fluvial systems in the Mediterranean region. Geomorphology, 79(3-4): 311-335.

Hope A., Bart R. 2012. Evaluation of a Regionalization Approach for Daily Flow Duration Curves in Central and Southern California Watersheds. J. Am. Water Res. Associat., 48 (1): 123-133.

Kiss T., Fiala K., Sipos G. 2008. Alterations of channel parameters in response to river regulation works since 1840 on the Lower Tisza River (Hungary). Geomorphology, 98: 96-110.

Klimek K., Latocha A. 2007. Response of small mid-mountain rivers to human impact with particular reference to the last 200 years; Eastern Sudetes, Central Europe. Geomorphology, 92(3-4): 147-165.

Kondolf G.M. 1997. Hungry water: Effects of dams and gravel mining on river channels. Environ. Manage., 21(4): 533551.

Korpak J. 2007. The influence of river training on mountain channel changes (Polish Carpathian Mountains). Geomorphology, 92(3-4): 166-181.

Longobardi A., Villani P. 2013. A statistical, parsimonious, empirical framework for regional flow duration curve shape prediction in high permeability Mediterranean region, J. Hydrol., 507: 174-185.
Macklin M.G., Jones A.F., Lewin J. 2010. River response to rapid Holocene environmental change: evidence and explanation in British catchments. Quarter. Sci. Rev., 29(13-14): 1555-1576.

Mendicino G., Senatore A. 2013. Evaluation of parametric and statistical approaches for the regionalization of flow duration curves in intermittent regimes. J. Hydrol., 480: 19-32.

Nádudvari Á., Czajka A. 2014. Statistical Calculations of the Tisza River Channel Changes Along Vezseny and Martfu (Hungary) From 1873-2010. Carpath. J. Earth Environ. Sci., 9(2): 57-70.

Parker C., Clifford N.J., Thorne C.R. 2011. Understanding the influence of slope on the threshold of coarse grain motion: Revisiting critical stream power. Geomorphology, 126(1-2): 51-65.

Rinaldi M., Surian N., Comiti F., Bussettini M. 2013. A method for the assessment and analysis of the hydromorphological condition of Italian streams: The Morphological Quality Index (MQI). Geomorphology, 180-181: 96-108.

Schoor M.M., Wolfert H.P., Maas G.J., Middelkoop H., Lambeek J.J. 1999. Potential for floodplain rehabilitation based on historical maps and present-day processes along the River Rhine, The Netherlands. Floodplains : Interdisci. Appr., 163: 123-137.

Searcy J.K. 1959. Flow-duration curves. Manual of Hydrology: Part 2, Low-Flow Techniques. Geology Survey watersupply paper 1542-A: 1-33.

Toonen W.H.J. 2015. Flood frequency analysis and discussion of non-stationarity of the Lower Rhine flooding regime (AD 1350-2011): Using discharge data, water level measurements, and historical records. J. Hydrol., 528 (November): 490-502.

Verstraeten G., Van Rompaey A., Poesen J., Van Oost K., \& Govers G. 2003. Evaluating the impact of watershed management scenarios on changes in sediment delivery to rivers? Hydrobiologia, 494: 153-158.

Williams M., Zalasiewicz J., Davies N., Mazzini I., Goiran J. P., Kane S. 2015. Humans as the third evolutionary stage of biosphere engineering of rivers. Anthropocene, 7: 57-63.

Wishart D., Warburton J., Bracken L. 2008. Gravel extraction and planform change in a wandering gravel-bed river: The River Wear, Northern England. Geomorphology, 94(1-2): 131-152.

Yuill B.T., Gaweesh A., Allison M.A., Meselhe E.A. 2015. Morphodynamic evolution of a lower Mississippi River channel bar after sand mining. Earth Surf. Proc. Land., 41, 4: 526-542

Zawiejska J., Wyzga B. 2010. Twentieth-century channel change on the Dunajec River, southern Poland: Patterns, causes and controls. Geomorphology, 117(3-4): 234-246.

Zawiejska J., Wyżga B., Radecki-Pawlik A. 2015. Variation in surface bed material along a mountain river modified by gravel extraction and channelization, the Czarny Dunajec, Polish Carpathians. Geomorphology, 231: 353-366. 